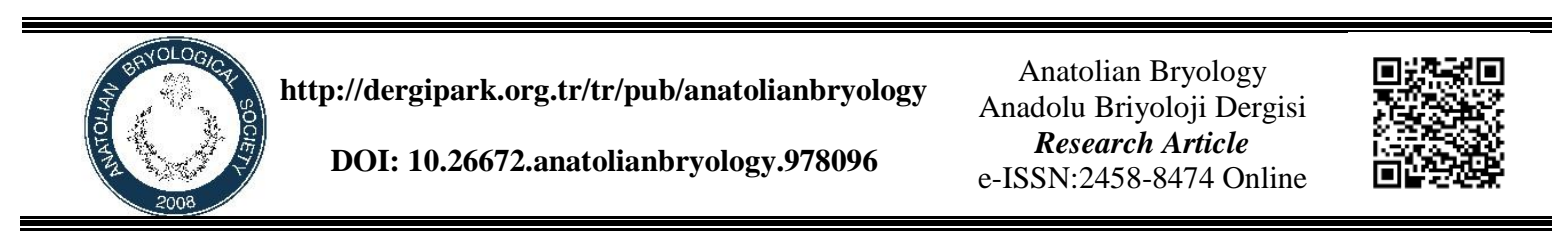

\title{
Syntrichia ruraliformis (Besch.) Mans., Hypnum andoi A.J.E.Sm. ve Platyhypnidium riparioides Dixon Etanol Ekstraktlarının HCT116 Hücre Canlılığı Üzerindeki Etkilerinin Spektroskopik Açıdan İncelenmesi
}

Hilal ZENGiN KÖKSAL ${ }^{1}$ (D), Dilşad ÖZERKAN²* (D), Ergin Murat ALTUNER ${ }^{3}$ iD, Kerem CANLI $^{4}$ (D)

\author{
${ }^{I}$ Kastamonu Üniversitesi, Fen Bilimleri Enstitüsü, Kastamonu, TÜRKIYE \\ ${ }^{2}$ İstinye Üniversitesi Sağllk Bilimleri Fakültesi, İstanbul, TÜRKIYYE \\ ${ }^{3}$ Kastamonu Üniversitesi, Fen Edebiyat Fakültesi, Biyoloji Bölümü̈, Kastamonu, TÜRKIYE \\ ${ }^{4}$ Dokuz Eylül Üniversitesi, Fen Bilimleri Fakültesi, Biyoloji Bölümü, İzmir, TÜRKIYY
}

\begin{abstract}
Received: 03 August $2021 \quad$ Revised: 01 September 2021 $\quad$ Accepted: 08 September 2021
Öz

Kolon kanseri neredeyse her y1l bir milyondan fazla yeni tanıların ortaya koyulduğu ve dünyada en sık rastlanan üçüncü kanser türüdür. Her yaş grubunda görülebildiği gibi kalıtımsal kökenli değildir. Bu veriler göz önüne alındığında kanserin tedavisi için yeni ilaç kombinasyonlarının araştırılması önemli bir ihtiyaçtır. Bu çalışmada, anti-kanser aktivitesi bilinmeyen Syntrichia ruraliformis (Besch.) Mans., Hypnum andoi A.J.E.Sm, Platyhypnidium riparioides Dixon karayosunu türlerinden elde edilen ekstraktlarının HCT116 kolon kanser hücre hatlarına karșı etkileri değerlendirilmiştir. Karayosunu türlerinin etil alkol çözücüsünde elde edilen ekstrelerinden, DMSO ile stok solüsyonlar hazırlanarak, çeşitli konsantrasyonlarda sitotoksite test (MTT) deneyleri yapılmıştır. HCT116 serisinde bulunan tüm karayosunu türlerinin $\mathrm{IC}_{50}$ değerlerine göre belirlenen dozlar aynı şekilde mezenkimal kök hücrelere $(\mathrm{MKH})$ uygulanmıştır. Ayrıca, Fourier transform kızılötesi (FTIR) spektroskopisi üç karayosununa maruz kalan kanser hücrelerini analiz etmek için kullanılmıştır. Sonuç olarak, karayosunu türlerinin HCT116 kolorektal kanser hücre hattına karş1 yüksek oranda antiproliferatif etki gösterdiği, bunun aksine MKH hücrelerinde letal olmadığı tespit edilmiştir. Ayrıca, FTIR spektrumu ile elde edilen sonuçların tüm hücre proliferasyonu verileriyle paralel seyrettiği moleküler düzeyde de belirlenmiştir. Tüm sonuçların 1şı̆̆ında bu karayosunu türlerinin, biyoaktif bileşenleri belirlendiği takdirde, potansiyel kanser ilacı olma özelliğine sahip olduğu düşünülmektedir.
\end{abstract}

Anahtar kelimeler: Briyofit, anti-proliferatif, kolorektal kanser, FTIR

Spectroscopic Investigation of the Effects of Syntrichia ruraliformis (Besch.) Mans., Hypnum andoi A.J.E.Sm. and Platyhypnidium riparioides Dixon Ethanol Extracts on HCT116 Cell Viability

Abstract
Colon cancer is the third most common type of cancer in the world, with more than a million new diagnoses every year. As can be seen in all age groups, it is not inherited. Considering these data, it is an important need to research new drug combinations for the treatment of cancer. In this study, the effects of extracts obtained from Syntrichia ruraliformis (Besch.) Mans., Hypnum andoi A.J.E.Sm, Platyhypnidium riparioides Dixon bryophyte species with unknown anticancer activity against HCT116 colon cancer cell lines were evaluated. Cytotoxicity test (MTT) experiments were performed at various concentrations by preparing stock solutions with DMSO from extracts of moss species obtained in ethyl alcohol solvent. The doses determined according to the $\mathrm{IC}_{50}$ values of all moss species in the HCT116 series were applied to the mesenchymal stem cells (MSCs) in the same way. In addition, Fourier transform infrared (FTIR) spectroscopy was used to analyze cancer cells exposed to three mosses. As a result, it was determined that moss species showed a high antiproliferative effect against HCT116 colorectal cancer cell line, but on the contrary, it was not lethal in MSC cells. In addition, it was determined at the molecular level that the results obtained with the FTIR spectrum were parallel to the cell proliferation data. In the light of all the results, these Bryophyte species are considered to be potential cancer drugs if their bioactive components are determined.

Key words Bryophyte, ant-proliferative, colorectal cancer, FTIR

* Corresponding author: dilsadokan@ gmail.com

(C) 2021 All rights reserved / Tüm haklarl saklıdır.

To cite this article: Köksal H.Z. Özerkan D. Altuner E.M. Canlı K. 2021. Syntrichia ruraliformis (Besch.) Mans., Hypnum andoi A.J.E.Sm. ve Platyhypnidium riparioides Dixon Etanol Ekstraktlarının HCT116 Hücre Canlılı̆̆ Üzerindeki Etkilerinin Spektroskopik Açıdan Incelenmesi. Anatolian Bryology. 7:2, 109-118.

(c) (1) () This work is licensed under a Creative Commons Attribution-Non Commercial 4.0 International License. 


\section{Giriş}

Kolorektal kanser (KRK), kadınlarda ve erkeklerde benzer insidans oranıla küresel olarak en yaygın kanserlerden biridir. Geniş bir morbidite ve mortalite oranıyla dünya çapında her yıl, bir milyondan fazla yeni KRK vakası teşhis edilmektedir. Kolon kanseri çoğunluğu sporadik olarak görülmekle beraber kalıtımsal mutasyon belirlenmemiştir. Epitel hücrelerde gerçekleşen genetik-epigenetik değişikliklerden kaynaklandığ gibi, tümör stroma ilişkisinin ve tümörün bulunduğu mikroçevrenin, tümöre karşı meydana gelen immün yanıtın, kolon kanseri patogenezinde önemli bir yer tuttuğu da bilinmektedir (McLean ve ark., 2011; Parizadeh ve ark., 2019).

Karayosunları evrimsel olarak bakıldığında, mantarlardan ve alglerden daha gelişmiş, çiçekli bitkilerden ve eğreltilerden daha ilkel canlılardır. Karasal bitki topluluğunun en büyük ikinci grubunu oluşturmaktadır. Ekosistemin önemli bir parçası olan bryofitlerin, potansiyelini belirlemeye yönelik çalışmalar Türkiye'de giderek artmaktadır. Güneydoğu Anadolu, briyofitler açısından en çok araştırılan bölgeler arasında olmasına rağmen, hala briyofitler için araştırılması gereken birçok alan vardır (Mezaka ve Znotina, 2006; Mezaka ve ark., 2008; Başer, 2016, Dikmen ve Keçeli, 2017; Erdağ ve Kürschner, 2017; Kırmacı ve Ağcagil, 2018). Yapılarında bulunan oligosakkaritler, polisakkaritler, aminoasitler, yağ asitleri, aromatik ve fenolik bileşikler gibi kendine özgü kimyasal bileşenleri sayesinde antikanser aktivesine sahip oldukları bilinmektedir (Singh ve Srivastava, 2013).

Karayosunlarına ait birçok çalışma söz konusu olmakla birlikte, kanser üzerine etkileri hakkında araştırılması gereken oldukça geniş bir alan vardır. Biyolojik olarak aktif kimyasalların belirlenmesi için, Ulusal Kanser Enstitüsü'nün briyofit kayıtları incelenmiştir. Buna göre, 1977'de Maryland'den bir yosun özü, KB (Oro-laringal Skuamöz Karsinoma) hücre kültüründe sitotoksisite göstermiştir. Fakat 1980'e kadar briyofitlerde antitümör etkisi keşfedilememiştir. $\mathrm{Bu}$ yüzden 1980-1981 yılları arasında briyofitlerin toplanması, taranması ve üzerine çalışmalar yapılması daha da artmıştır (Spjut ve ark., 1986).

Yapılan bir briyofit tarama çalışmasında 43 türün aktif olduğu, 75 türün fareler için toksik olduğu antitümör ajanlar için birçok türün bulunduğu tespit edilmiştir. Brachytheciaceae, Hypnaceae familyalarının en fazla aktivite gösterdiği gözlenmiştir. En eski kara bitkileri olarak kabul edilen briyofitler, farklı stres türlerine karşı mücadele etmek için bir dizi ikincil metabolit sentezlerler. $\mathrm{Bu}$ fitokimyasalların varlığından dolayı enfeksiyon, yıpranma, radyasyon, sıcaklık, tuzluluk dalgalanmaları ile başa çıkabilirler (Dey ve Mukherjee, 2015). Hem dünyada hem Türkiye'de oldukça zengin floraya sahip karayosunlarının antikanser çalışmaları yetersiz kalmaktadır. Dolayısıyla bu çalışmada, Syntrichia ruraliformis, Hypnum andoi ve Platyhypnidium riparioides türü karayosunlarının etil alkol ekstraktlarının, HCT116 kolorektal kanser hücre proliferasyonuna ve moleküler değişikliklere etkisinin spektroskopik açıdan incelenmesi hedeflenmiştir.

\section{Gereç ve Yöntemler \\ 2.1 Karayosunu Türleri Ekstraksiyonu}

Çalışmada $S$. ruraliformis (K1), $H$. andoi (K2) ve $P$. riparioides (K3) karayosunu türleri için diğer çözücü maddelere kıyasla, düşük sıcaklıkta vakum altında kolay buharlaştırılabilmesi ve polaritesi göz önünde bulundurularak etil alkol çözücüsü kullanılmıştır. Ekstraksiyon sırasında her üç karayosunu havanda toz haline getirilmiştir. 0,5 gr karayosunu hassas terazide tartılarak üzerlerine 50 ml \%99,9 saflıkta etanol eklenmiştir. 130 rpm'de orbital çalkalayıcının (WiseShake, Kore) üzerine koyularak, bir hafta süreyle karıştırılmaya bırakılmıştır. Süre sonunda ekstraktlar çalkalayıcıdan alınarak Whatman No:1 filtre kağıdından süzülmüş ve etil alkol ekstraktlarından döner buharlaştırıcıda (Heidolph) vakum altında 130-150 rpm, 40-45 ${ }^{\circ}$ 'de çözücü maddenin uzaklaştırılması sağlanmıştır (Yetgin ve ark. 2018). Çözücünün buharlaştığı balon içerisinde kalan karayosunları kazılarak ependorf bir tüp içine alınmıştır.

\subsection{Kolorektal Karsinoma Hücre Serisinin Hazırlanması}

Çalışmada insan kolorektal karsinoma (ATCC) hücre hatları olan HCT116 kullanılmıştır. Hücreler T75 kültür kapları içerisine alınarak üzerine \%10 FBS ve \%1 penisilin-streptomisin içeren DMEM koyulmuştur. $37^{\circ} \mathrm{C}, \% 5 \mathrm{CO}_{2}$ içeren inkübatöre hücrelerin çoğalması ve farklılaşması için kaldırılmıştır. Etil alkol ekstraktlarının stok çözeltileri DMSO $(5 \mathrm{mg} / \mathrm{mL})$ ile hazırlmıştır. Stok çözeltiler istenilen konsantrasyonlarda besi yeri ile seyreltilerek doz ayarlaması yapılmıştır. Üç karayosunu türü için belirlenen konsantrasyon aralığı Tablo 1'de gösterilmiştir.

Tablo 1. K1, K2, K3 karayosunu türlerine uygulanan doz konsantrasyonları

\begin{tabular}{cc} 
Karayosunu Türleri & $\begin{array}{c}\text { Belirlenen } \\
\text { Konsantrasyon } \\
(\boldsymbol{\mu g} / \mathbf{m L})\end{array}$ \\
\hline $\mathrm{K} 1, \mathrm{~K} 2, \mathrm{~K} 3$ & $100 / 90 / 80 / 70 / 60 / 50$ \\
\hline
\end{tabular}


T75 kültür kapları içerisindeki hücreler $\% 80$ doluluğa ulaştığında, hücrelere farklı konsantrasyonlarda etil alkol çözücüsü ile hazırlanmış $\mathrm{K} 1, \mathrm{~K} 2, \mathrm{~K} 3$ ekstreleri uygulanmıştır. Hücrelerde meydana gelen sitotoksik etki MTT (3(4,5-dimetiltiyazol-2-il)-2,5-difeniltetrazolium bromid) yöntemi kullanılarak incelenmiştir. Oluşan formazan çözülerek $570 \mathrm{~nm}$ dalga boyunda multimode mikroplaka (BioTek, ABD) okuyucuda absorbansları ölçülmüştür. Canlı hücrelerin yüzdesi hesaplanırken Eşitlik 1'de ki denklem kullanılmıştır. Yaşayan hücreler\% $\% \sum$ Boyanmamış hücreler / $\sum$ Hücreler $\times 100$

Her kuyucuk için 1000 hücre olacak şekilde 96'lık kuyucuklar içerisine hücre ekimi gerçekleştirilmiştir. Bu işlemin ardından hazırlanan karayosunu ekstrelerine ait dozlardan $10 \mu \mathrm{l}$ alınarak kuyucuklara uygulanmış ve $37^{\circ} \mathrm{C}, \% 5 \mathrm{CO}_{2}$ içeren inkübatörde 72 saat bekletilmiştir. Süre sonunda 96'lı plaka içerisindeki her kuyucuğa $10 \mu \mathrm{l}$ MTT reaktifi koyularak 4 saat $37^{\circ} \mathrm{C}, \% 5 \mathrm{CO}_{2}$ içeren inkübatörde bekletilmiştir ve mikroplaka (BioTek, ABD) okuyucuda $570 \mathrm{~nm}$ dalga boyunda absorbansları ölçülmüştür. MTT analizlerinin sonucunda doz/cevap eğrileri hazırlanarak, bileşiklerin $\mathrm{IC}_{50}$ değeri (hücrelerin \%50'sinin büyümesini inhibe eden konsantrasyon) hesaplanıp bu parametreye göre ekstraktın etkinlikleri karşılaştırılmıştır. DMSO ve etil alkol negatif kontrol olarak kullanılmıştır. $\mathrm{Bu}$ kontroller, hücrenin hayatta kalması üzerindeki etkiyi belirlemek için 96'lı plakalara ayrı gruplar halinde eklenmiştir. Graphpad Prism 9.1.0 programı kullanılarak bileşiklerin $\mathrm{IC}_{50}$ değeri hesaplanmıştır ve bu parametreye göre ekstraktın etkinlikleri karşılaştırılmıştır (Özerkan ve ark. 2021).

\subsection{Mezenkimal Kök Hücre Serisinin Hazırlanması}

Kullanılan hücreler KÜ-HADYEK 2018-10 Etik Kurul İzni ile hazırlanan MKH hattının P6 aşamasındaki hücreler olup, Kastamonu Üniversitesi Deney Hayvanları Yerel Etik Kurulu'nun 25.03.2021 tarihli 2 sayılı toplantısının 12 sayılı kararı ile kullanılması için etik kurul onayı gerekmediği ayrıca onaylanmıştır.

\%80 doluluğa ulaşan mezenkimal kök hücrelere $(\mathrm{MKH})$ tripsinizasyon işlemi uygulanarak her kuyucuk için 1000 hücre olacak şekilde 96'lık kuyucuklara hücre ekimi gerçekleştirilmiştir. Kuyucuklara \%10 FBS ve \%1 penisilinstreptomisin içeren $\alpha$-MEM eklendi. Hücrelerin yüzeye yapışması için bir gece $37^{\circ} \mathrm{C}, \% 5 \mathrm{CO}_{2}$ ve $\% 90$ nem içeren inkübatörde bekletilmiştir. Süre sonunda her bir kuyucuktan $25 \mu \mathrm{L}$ besiyeri çekilerek, kuyucuklara hazırlanan karayosunu ekstraktlarına ait dozlardan $25 \mu \mathrm{L}$ eklenmiştir. Hücreler inkübatöre kaldırılarak 72 saat bekletilmiştir. Süre sonunda kuyucuklardaki sıv1 kısım tamamen çekilerek $225 \mu \mathrm{L}$, penisilinstreptomisin içeren $\alpha$-MEM eklenmiştir. Üzerine 25 $\mu \mathrm{L}$ MTT reaktifi eklenerek 4 saat $37^{\circ} \mathrm{C}, \% 5 \mathrm{CO}_{2}$ içeren inkübatörde bekletilmiştir. Süre sonunda kuyucuklardaki sıvı tamamen çekilerek atılmış ve kuyucuklara $250 \mu \mathrm{L}$ isopropil alkol koyularak oluşan formazan çözülmüştür. Steril haldeki farklı bir 96'lık plaka içerisine kontrol, örnek ve kör çözeltilerinden $200 \mu \mathrm{L}$ koyularak multimode mikroplaka (BioTek, ABD) okuyucuda $570 \mathrm{~nm}$ dalga boyunda, kuyucukların absorbansları ölçülmüştür (Emin ve ark. 2020).

\section{4 İstatiksel Analiz}

Deneylerin sonuçları tek yönlü ANOVA tarafindan Graphpad Prism 9.1.0 programı kullanılarak çoklu karşılaştırma testi ile istatistiki yönden analiz edilmiştir. Kontrol grubu ortalamasına karşı diğer grupların ortalamalarının karşılaştırılması Dunnett testi ile gerçekleştirilmiştir. $\mathrm{p}<0,05$ istatistiksel olarak anlamlı kabul edildi. Sonuçlar ortalama \pm SEM olarak verilmiştir.

\subsection{FTIR Analizi İçin Numune Hazırlanması}

FTIR analizi sadece karayosunu türlerinin önceden belirlenen $\mathrm{IC}_{50}$ konsantrasyonları kullanılarak yapılmıştır. İçerisinde HCT116 kontrol grubu, sisplatin uygulanmış HCT116 grubu ve K1, K2, K3 karayosunu ekstreleri uygulanmış HCT116 hücreleri bulunan $6^{\prime} l_{1}$ plaka $37^{\circ} \mathrm{C}, \% 5 \mathrm{CO}_{2}$ içeren inkübatörde 72 saat bekletilmiştir. 72 saat sonunda inkübe edilen hücreler 3 kez PBS ile santrifüjlenerek süpernatant kısım atılmış ve pellet kısmı DMEM ile çözdürülmüştür. Her bir karayosunu için ayrı lamlar etiketlenerek hücre süspansiyonu lamlar üzerine yayılmış, lamların kuruması için 24-48 saat çeker ocakta bekletilmiştir. Kuruyan lamlar üzerindeki örnekler kazılarak ependorf tüpler içerisine alınarak ATRFTIR (BRUKER Alpha, Almanya) cihazı ile analizleri yapılmıştır (Guleken ve ark. 2021).

\section{Bulgular}

\subsection{Hücre Canlılığı Bulguları}

Kullanılan karayosunu türlerinin dozları Tablo 1'de gösterilen aralıkta seçilerek, hücre proliferasyonuna etkileri belirlenip Şekil 1'de gösterilmiştir. HCT116 hücreleri ile kontrol grubu karşılaştırılmıştır. Tüm karayosunu gruplarında uygulanan konsantrasyonlardan hangisinin hücre canlılığını $\% 50$ inhibe ettiği belirlenmiştir. Etil alkol ile hazırlanmış K1, K2, K3 karayosunu ekstraktının kontrol grubuna kıyasla, uygulanan tüm konsantrasyonlarda HCT116 hücreleri üzerinde, 
canlılı̆̆ı azaltıcı yönde etki ettiği görülmüştür. Özellikle K1'de $70 \mu \mathrm{g} / \mathrm{mL}$, K2'de $50 \mu \mathrm{g} / \mathrm{mL}$ ve $\mathrm{K} 3$ 'de $50 \mu \mathrm{g} / \mathrm{ml}$ konsantrasyonlarda en iyi sonuçlar elde edilmiştir. Kolorektal kanser hücre serilerinde bulunan $\mathrm{IC}_{50}$ değerlerine göre belirlenen dozlar aynı şekilde MKH'lere de uygulandi. Tüm karayosunlarının mezenkimal kök hücre canlılığ 1 üzerinde çok önemli bir etkisi olmadığı gözlenmiştir. Şekil 1'de kontrol grubu ile kıyaslandığında özellikle K3 karayosunu türünde $70 \mu \mathrm{g} / \mathrm{mL}$ konsantrasyonun etkili olduğu görülmüştür. Sonuçlara göre elde edilen doz/cevap eğrileri ve $\mathrm{IC}_{50}$ değerleri Şekil 2'de verildi. Sisplatinin $\mathrm{IC}_{50}$ değeri yaklaşık olarak 18,90 $\mu \mathrm{M}$ 'dır. Etil alkol ile hazırlanmış K1, K2 ve K3 karayosunu türlerinin üçünün de sisplatin ile hazırlananlara göre HCT116 üzerinde daha etkili olduğu görülmüştür.
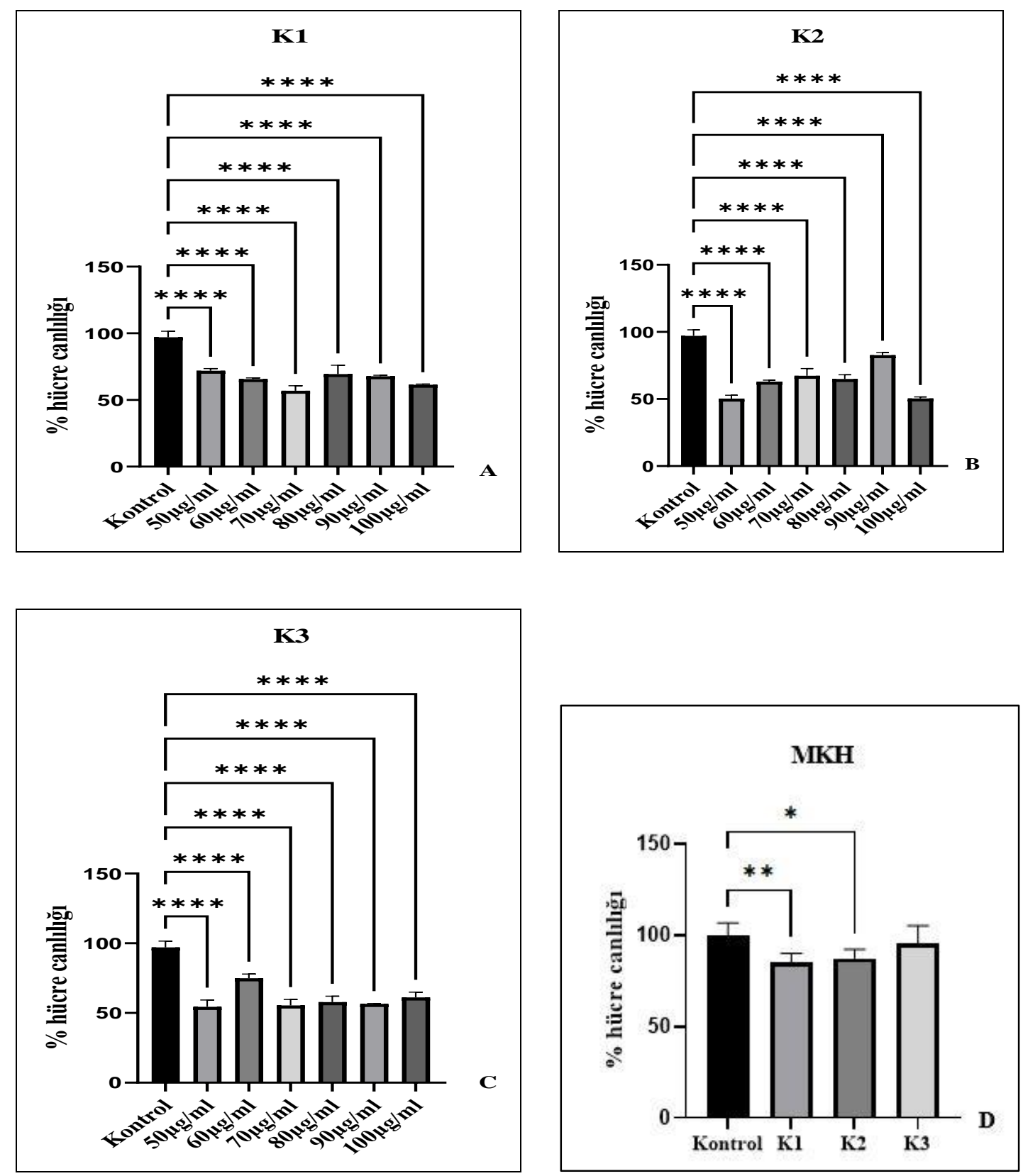

Şekil 1.72 saat sonunda hücre canlılığı (\%) MTT testi ile belirlenmiştir. K1, K2 ve K3 ekstraksiyonu doza bağlı bir şekilde kolorektal kanser hücre dizisi HCT116'da belirgin hücre ölümünü indüklemiştir. Veriler, her koşul için üç bağımsız deneyden alınmıştır. Kontrol grubuna göre uygulanan karayosunu dozları istatiksel olarak değerlendirilmiştir (a-c). K1, K2 ve K3 türlerinde en etkili IC 50 dozları belirlendikten sonra mezenkimal kök hücrelerine uygulanmış ve 72. Saatin sonundaki canlılık oranları kontrol grubu ile karşılaştırılmıştır (d) $\quad(* * * * \mathrm{p}<0,0001 ; * * * \mathrm{p}<0,001 ; * * \mathrm{p}<0,01 ; * \mathrm{p}<0,05)$ 


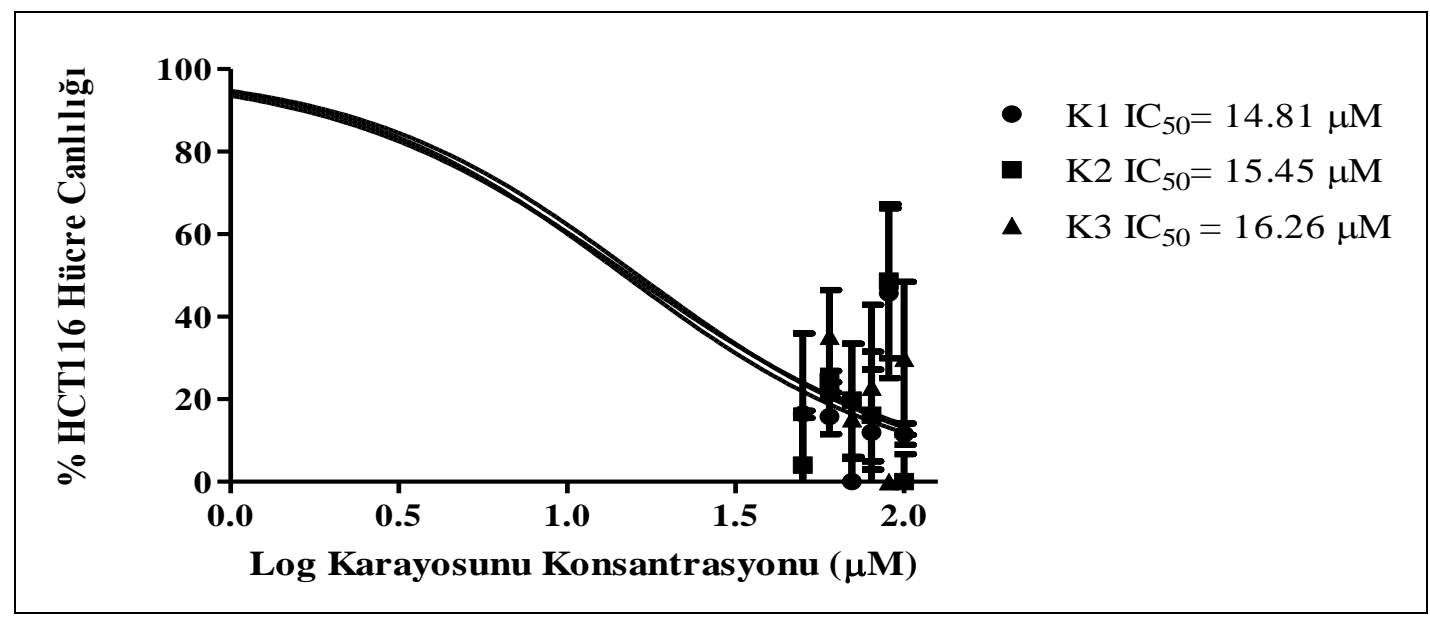

Şekil 2. Etil alkol çözücüsüyle hazırlanmış olan K1, K2, K3 karayosunu ekstrelerinin $\mathrm{IC}_{50}$ değerlerine ait doz/cevap eğrileri

\subsection{Morfolojik Bulgular}

HCT116 kontrol grubu koloni halinde yüzeye yayılmış olarak gözlenmiştir (Şekil 3a). Karayosunu uygulamaları sonucunda hücrelerin hacimlerinde bir artış tespit edilerek, hücrelerin bazılarında iğsi şekil artışı saptanmıştır (Şekil 3 b, c). Bazı hücrelerde ise büzülme ve yuvarlak morfoloji belirlenmiştir (Şekil 3d). Ayrıca hücreler arası bağlantıların azalarak kolonileşmelerin de azaldığı izlenmiştir (Şekil 3).

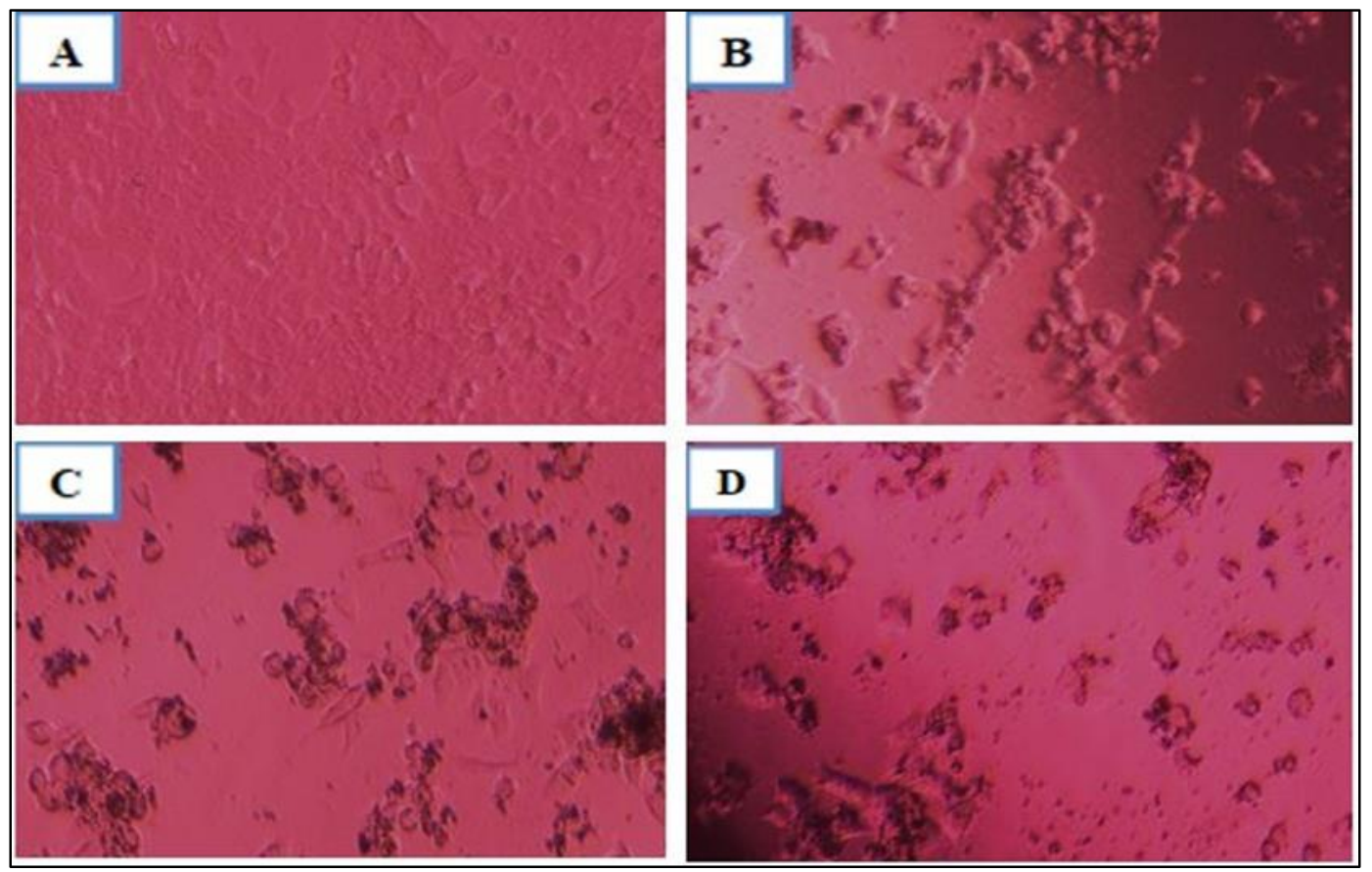

Şekil 3. Karayosunu türleri uygulanmış HCT116 kanser hücrelerinin morfolojik görüntüleri (büyütme $\mathrm{X} 100)$

\subsection{FTIR Bulguları}

Tüm ATR-FTIR spektrumları oda sıcaklığında 4000 ile $450 \mathrm{~cm}^{-1}$ arasındaki spektral bölgede elde edilmiştir. Bireysel hücresel bileşenlerdeki niceliksel değişiklikleri analiz etmek için, tek tek bileşenlerin belirli bantlar için soğurma yoğunluğunun oranları belirlenmiştir. Spektral normalizasyon, baseline düzeltmesi sonrası uygun spektral aralıktaki eşit alan açısından (lipidler için $3300-2800 \mathrm{~cm}^{-1}$, proteinler için $1800-1200 \mathrm{~cm}^{-1}$, nükleik asitler için 1200-900 $\mathrm{cm}^{-1}$ ) gerçekleştirilmiştir. Absorbans değerleri, titreşim tipine atanan ilgili dalga numaralarında okunmuştur (Şekil 4). 


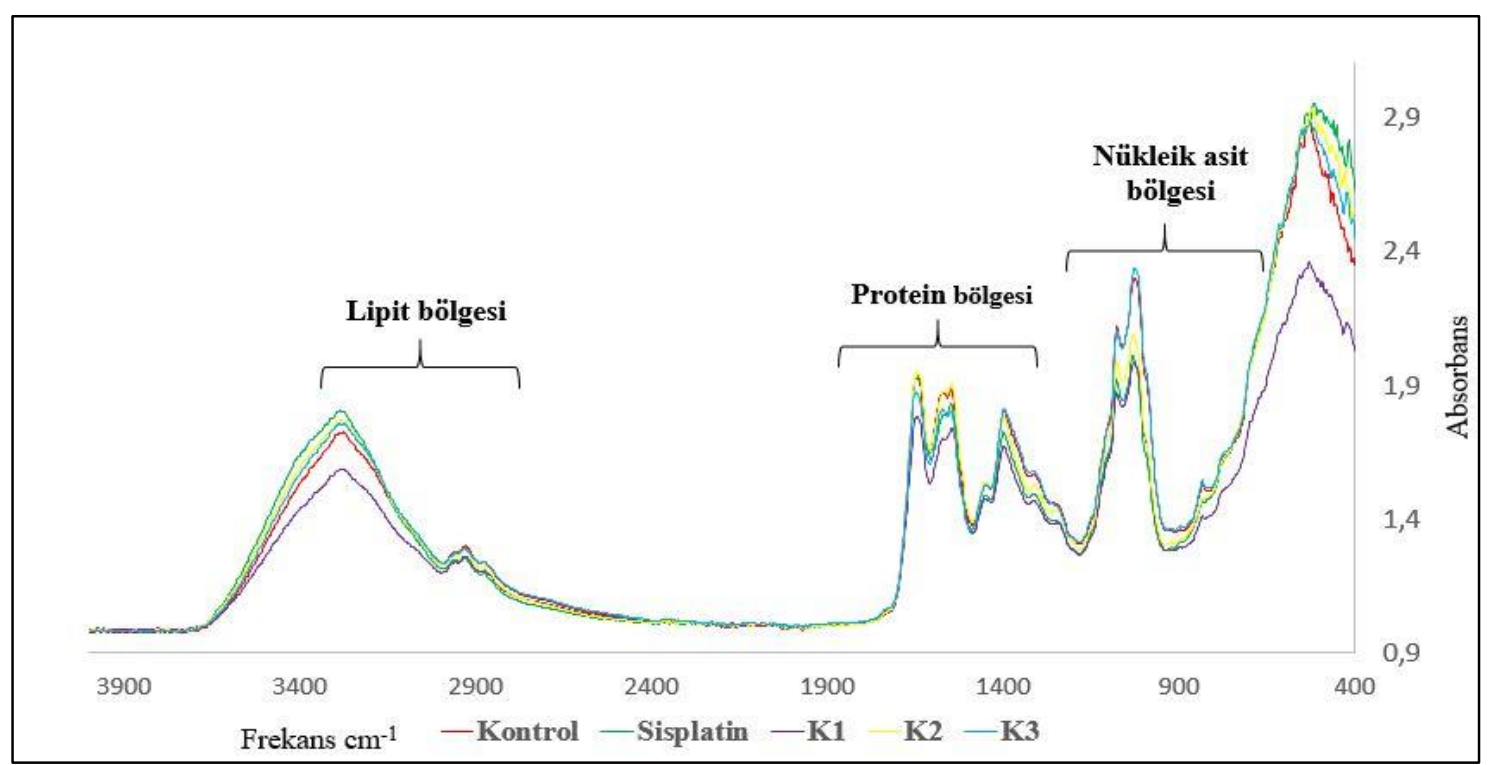

Şekil 4. Kontrol K1-K3 karayosunu ekstraktları ve sisplatin uygulanmış HCT116 hücrelerinden elde edilen FTIR grafikleri

$3274 \mathrm{~cm}^{-1}$ 'de tespit edilen $\mathrm{O}-\mathrm{H}$ simetrik germe bandı piki için $\mathrm{K} 1$ türü, kontrol grubuna göre düşük bulunmuştur. K2 ve K3 türleri uygulanmış HCT116 hücrelerinde bu pik kontrol grubundan daha yüksek gözlenmiştir. Bunun haricinde $2952 \mathrm{~cm}^{-1}$ 'de $\mathrm{CH}_{2}$ asimetrik germe piki, $2922 \mathrm{~cm}^{-1}$, de asil zincirlerinin $\mathrm{CH}_{2}$ 'sinin asimetrik gerilme titreşim pik değerlerinde kontrol grubuna göre diğer gruplarda genel olarak bir azalma görülmüştür. $2871 \mathrm{~cm}^{-1}$, de $\mathrm{CH}_{3}$ simetrik germe piki ve $2854 \mathrm{~cm}^{-1}$ 'de $\mathrm{CH}_{2}$ simetrik piki tespit edilmiştir. $\mathrm{Bu}$ piklerde kontrol ve K3 karayosunu türünde benzer pikler görülürken diğer gruplarda ise daha düşük pik değerleri görülmektedir (Şekil 5).

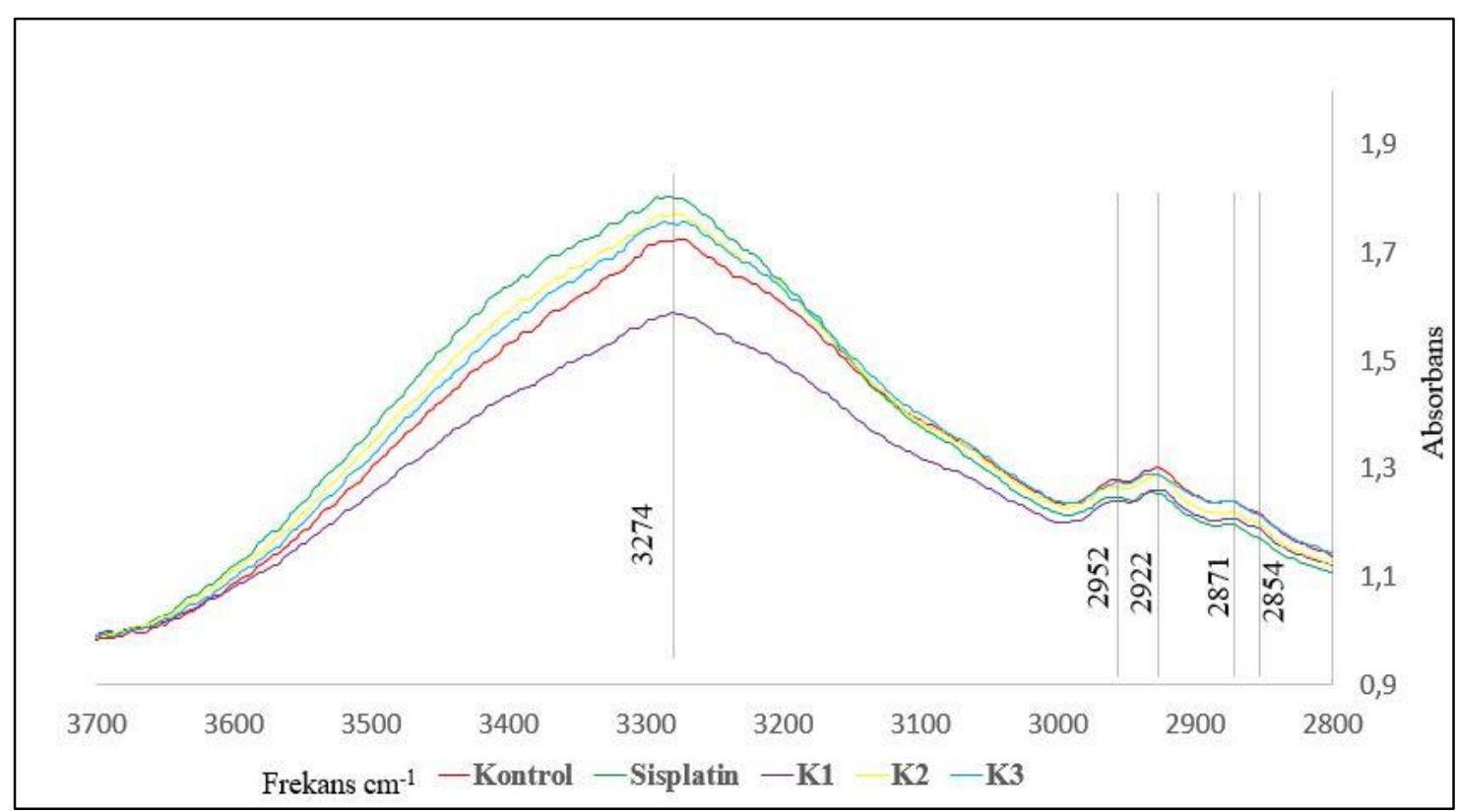

Şekil 5. 3300-2800 $\mathrm{cm}^{-1}$ aralığı ayarlanmış lipit bölgesi karayosunu gruplarının HCT116 hücrelerine uygulanması sonucu görülen FTIR pik değerleri ve anlamları

Tüm gruplarda $1635 \mathrm{~cm}^{-1}$, de Amid I, 1570 ve 1539 $\mathrm{cm}^{-1}$, de Amid II, $1449 \mathrm{~cm}^{-1}$ de metil protein gruplarının asimetrik $\mathrm{CH}_{3}$ bükülmesi, $1392 \mathrm{~cm}^{-1}$, de $\mathrm{CH}_{2}$ asimetrik bükme, COO- gerilmesi (proteinler ve yağ asitleri) ve $1307 \mathrm{~cm}^{-1}$ de Amid III pikleri tespit edilmiştir. Amid I ve Amid II piklerinde K2 türü haricinde tüm piklerde belirgin azalma mevcuttur. Amid I pikinde K3 grubunda yaklaşık 5 $\mathrm{cm}^{-1}$ 'lik sola kayma söz konusudur. $1449 \mathrm{~cm}^{-1}$ pikinde, kontrol, K2 ve sisplatin grupları benzer 
pikler gösterirken, K1 ve K3 türlerinde gözle görülür derecede piklerde azalma mevcuttur. 1392 $\mathrm{cm}^{-1}, 1307 \mathrm{~cm}^{-1}$ ve $1241 \mathrm{~cm}^{-1}$ Amid III piklerinde ise kontrol ve $\mathrm{K} 3$ gruplarında benzer pikler saptanırken, diğer gruplarda pik yoğunluklarında belirgin azalma izlenmiştir (Şekil 6).

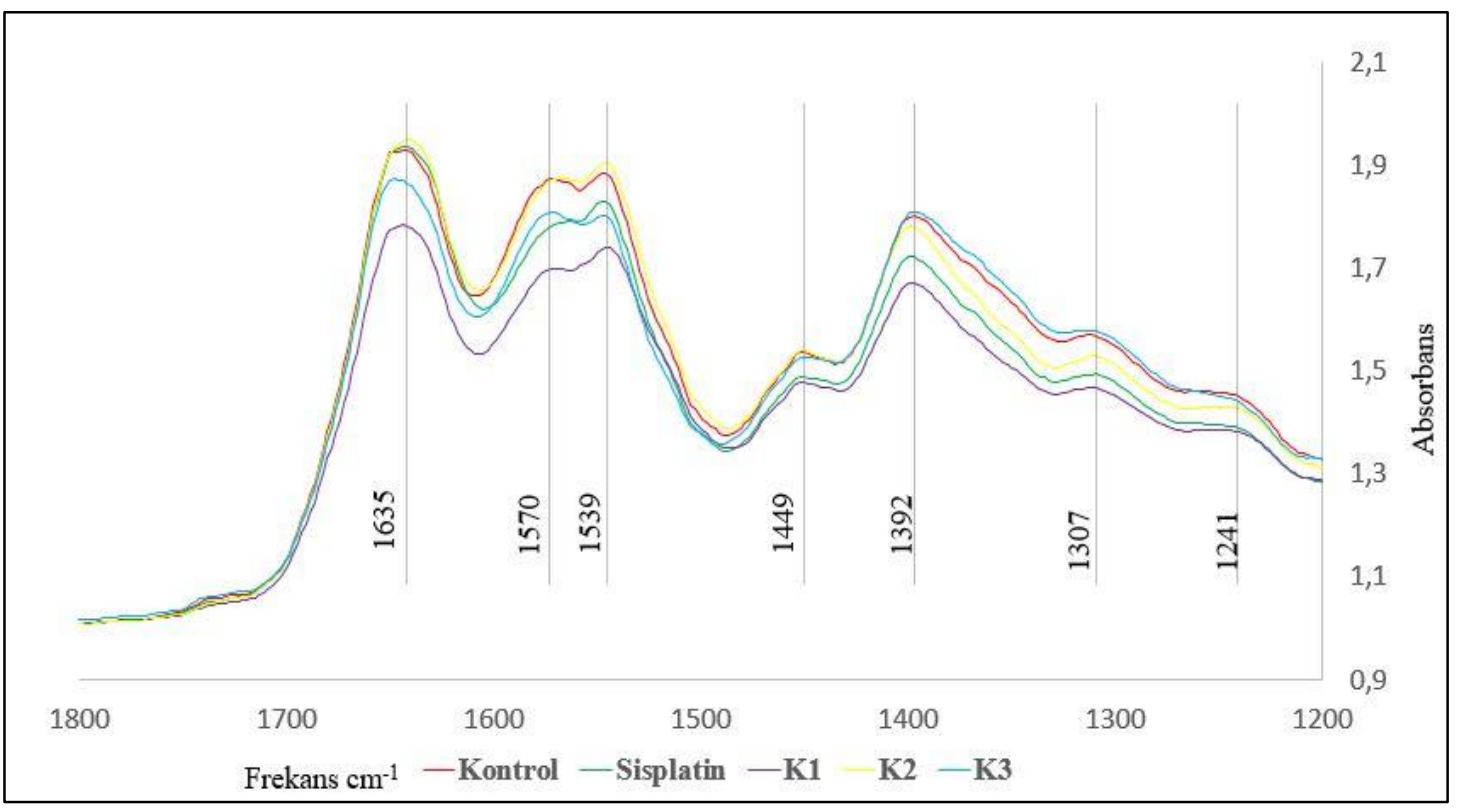

Şekil 6. 1800-1200 cm-1 aralığı ayarlanmış protein bölgesi karayosunu türlerinin HCT116 hücrelerine uygulanması sonucu görülen FTIR pik değerleri ve anlamları

$1072 \mathrm{~cm}^{-1}$, de nükleik asit bandında, $1021 \mathrm{~cm}^{-1}$, de RNA piki, $984 \mathrm{~cm}^{-1}$ 'de fosfodiester bölgesinde ve $835 \mathrm{~cm}^{-1}$ 'de DNA bölgesinde pikler belirlenmiştir. Tüm pik yoğunlukları incelendiğinde bu bantların hepsinde kontrol ve K3 karayosunu türünde benzer oranlar saptanırken; diğer tüm gruplarda bu oran azaldı (Şekil 7).

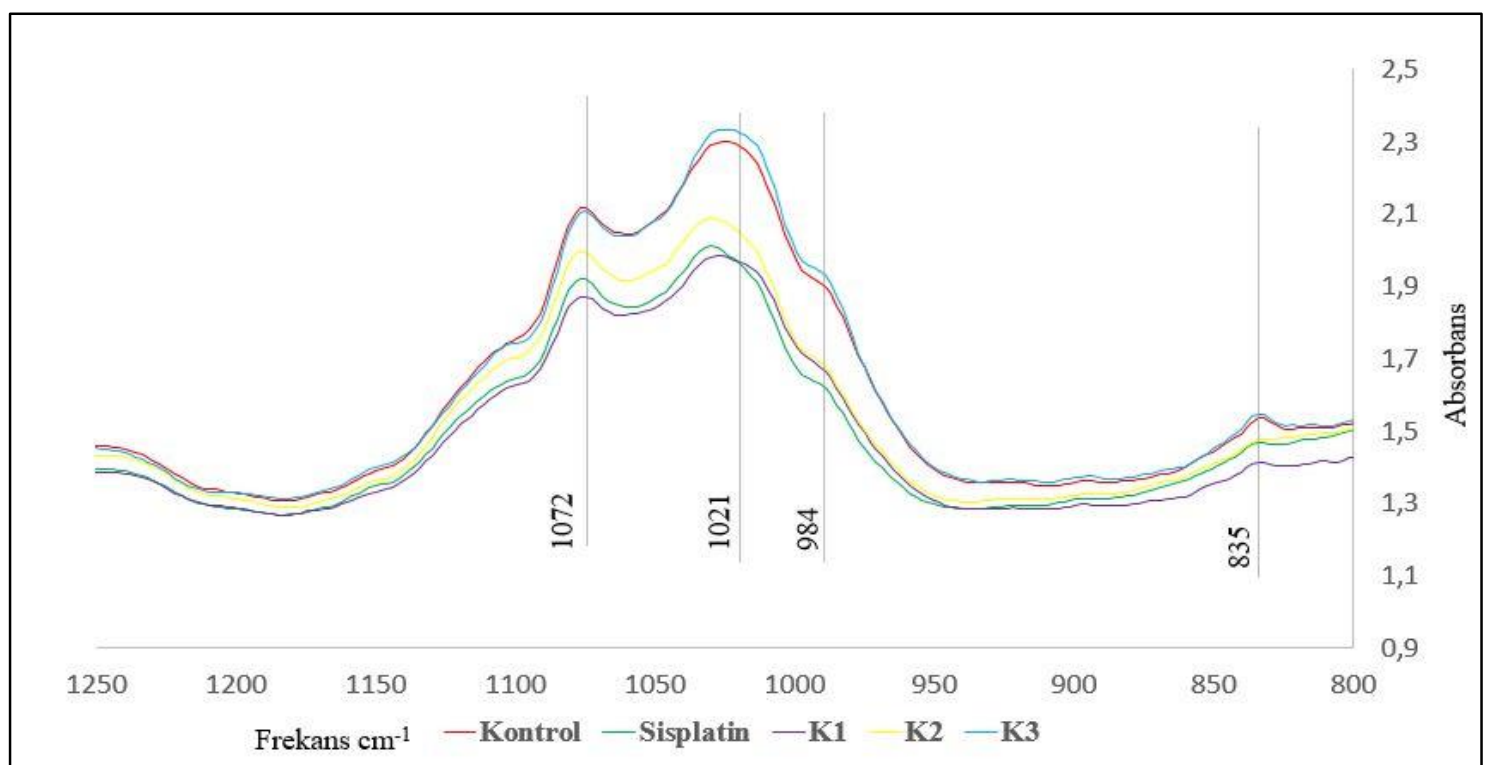

Şekil 7. 1200-900 $\mathrm{cm}^{-1}$ aralığı ayarlanmıs nükleik asit bölgesi karayosunu gruplarının HCT116 hücrelerine uygulanması sonucu görülen FTIR pik değerleri ve anlamları 


\section{Tartışma ve Sonuç}

Briyofitler bilinen en eski kara bitkileri olmakla birlikte faydaları insanların çoğu tarafından bilinmemektedir. Eczacilık ürünlerinde, bahçecilikte, evsel kullanım, inşaat, ilaç sektöründe kullanılmakla birlikte ekolojik açıdan da önemli bir yere sahiptirler (Saxena, 2004). Yapılarında bulunan terpenoidler, asetojenler, aromatik bileşikler kimyasal savunmalarında ve bariyer görevi görmede etkilidir (Asakawa ve Ludwiczuk, 2019). Karayosunlarına ait birçok çalışma olmasıyla birlikte, kanser üzerine etkileri hakkında araştırılması gereken oldukça geniş bir alan vardır.

Yapılan literatür taramasında Syntrichia ruraliformis, Hypnum andoi ve Platyhypnidium riparioides karayosunu türlerine ait antikanser çalışmasına rastlanmamıştır. Araştırmaların yetersizliği ve bryofitlerin biyoaktif bileşen açısından zenginliği bu çalışmanın gerçekleştirilmesine sebep olmuştur.

$\mathrm{Bu}$ türlerin familyalarına ait çalışmalara bakıldığında, 2021 yılında tarafımızca yapılan bir başka çalışmada $S$. ruralis türü HCT116 hücre proliferasyonunu azaltıcı etki göstermiştir. $\mathrm{IC}_{50}$ değeri $24,26 \mu \mathrm{g} / \mathrm{ml}$ bulunmuştur. Bu çalışma da $S$. ruraliformis türünün $\mathrm{IC}_{50}$ 'si daha düşük bulunmuştur (Özerkan ve ark. 2021). Başka bir çalışmada, birçok Briyofit türünün akut lenfoblastik $\mathrm{T}$ lösemi hastası dört yaşındaki beyaz bir kızın periferik kanındaki lenfosit T'nin öncüleri olarak insan fibroblastlarından oluşan CCRF-CEM hücreleri ve CCRF-CEM hattından elde edilmiş, alt klonlanmış ve kamptotesine dirençli CEM/C1 hücreleri üzerindeki sitotoksik etkileri incelenmiştir. Seçilen türler arasında Hypnaceae familyasına ait Hypnum lindbergii Mitt. ve Hypnum cupressiforme Hedw. türleri bu hücreler üzerinde sitotoksik etki göstermiştir. $\mathrm{IC}_{50}$ değerleri sırasıyla 490,78 $(\mu \mathrm{g} / \mathrm{mL})$ ve 397,96 $(\mu \mathrm{g} / \mathrm{mL})$ olarak bulunmuştur (Hawrył ve ark., 2018). Çanakkale İda dağından toplanan Hypnum cupressiforme Hedw. türünün metanol ektraktları küçük hücreli akciğer kanseri hücreleri ve HeLa insan servikal kanser hücreleri üzerinde yüksek oranda antiproliferatif etkiye sebep olmuştur (Yayıntaş ve ark., 2019). İlgili çalışmalara ait sonuçlar karşılaştırıldığında; tarafımızca kullanılan türlerin hücre canlılığını azaltıcı yönde daha düşük dozlarda daha fazla etkin olduğu ifade edilebilir.

ATR-FTIR yöntemi ile normal ve kanser hücrelerinde zar proteinleri ve lipidler arasındaki farklar gösterilmekte, kanser hücrelerine ilaç verildikten sonra apoptotik ve nekrotik ölüm tespit edilmektedir (Gieroba ve ark., 2020; Dunkunthod ve Chitsomboon, 2020; Serdiuk ve ark., 2020). Bu çalışmada, ATR-FTIR kullanılarak biryofit uygulamasının kanser hücrelerinde meydana getirdiği protein, lipid ve nükleik asitlerdeki değişimler incelenmiştir. Piklerin hücre ölümüyle herhangi bir ilişkisi olup olmadığını belirlemek için belirli piklerdeki değişikliklere bakılmıştır.

Amid I ve amid II arasındaki absorbans değeri, amid gruplarının gerilme titreşimleri, proteinlerdeki yapısal değişiklikleri ifade etmek için uygulanabilir (Ishida ve Griffiths, 1993). Kontrol grubunda (HCT116) amid I /amid II'nin ortalama değeri yaklaşık 1,014'tür ve karayosunu ekstreleri uygulanmış hücrelerde bu oranda artış gözlenmiştir. RNA/DNA absorbans oranının analizi ile nükleik asit içeriğindeki azalma belirlenebilir (Sahu ve ark., 2008). Tüm karayosunu türlerinde kontrol grubuna kıyasla RNA/DNA oranında bir artış gözlenmiştir. K1 ve K2 türleri uygulanmış HCT116 hücrelerinde kontrol grubuna göre amid I/DNA oranındaki artış, daha fazla kromatin yoğunlaşması ile sağlanabilir. Buna karşılık, K3'de gözlenen ters eğilim muhtemelen DNA'nın çift sarmalının enzimler yardımıyla açıldığı yoğun DNA replikasyonu ile ilişkilidir (Barth, 2007; Antonin ve Neumann, 2016). Yağ asitlerinde bulunan $\mathrm{CH}_{2}$ ve $\mathrm{CH}_{3}$ gruplarının simetrik ve asimetrik gerilme titreşimleri, 2800 ile $3000 \mathrm{~cm}^{-1}$ arasındaki bölgede bulunmaktadır. $\mathrm{CH}_{2}$ sayısına göre $\mathrm{CH}_{3}$ sayısının artmas1, apoptozis sirasinda lipid zincirlerinin değişebileceğini göstermektedir. Apoptozis sirasında $\mathrm{CH}_{2}$ 'nin simetrik ve antisimetrik gerilmesine atanan $2854 \mathrm{~cm}^{-1} \pm 3 \mathrm{~cm}^{-1}$ ve $2952 \mathrm{~cm}^{-1}$ $\pm 4 \mathrm{~cm}^{-1}$ bantları her grupta farklı etki göstermektedir. $2952 \mathrm{~cm}^{-1}$ ve $2854 \mathrm{~cm}^{-1}$ de $\operatorname{artan}$ lipid emilimi apoptoz ve nekroz için ortak bir belirteç olabilir, K1 ve K2 karayosunu ekstraklarında tespit edilebilir. Ancak K3 ve sisplatin uygulanmış gruplarda farklı sonuçlar ortaya çıkmıştır. Dolayısıyla, $\mathrm{CH}_{2} / \mathrm{CH}_{3}$ oranındaki artış veya azalma net bir sonuç elde edilmesini sağlamayabilir (Gasparri ve Muzio, 2003). Protein / lipid absorbans yoğunluğu $\mathrm{CH}_{2} / \mathrm{CH}_{3}$ oranı ile güçlü bir şekilde ilişkili olup (bu çalışmada amid I/lipidler), hücre zarı içindeki lipid ve protein dağılımındaki sapmalar hakkında ekstra bilgi sağlar. Amid I/lipid emme yoğunluğu oranları analiz edildiğinde, tüm karayosunu ekstraklarının hücre membranlarında bozukluklara yol açtığı saptanabilir. Hem metil $\left(\mathrm{CH}_{3}\right)$, hem de metilen $\left(\mathrm{CH}_{2}\right)$ gruplarının absorbansı incelendiğinde amid I/lipid oranında bir azalma söz konusudur. Bu durumun apoptoz ve nekroz sırasında olabileceğini düşündürmektedir. Hem apoptozun, hem de nekrozun aynı anda gerçekleşmesi olasılığı bulunmaktadır (Abdel-Rauf Ahmed ve ark., 2009). Düzensiz yapıdaki DNA'daki deoksiribozun iki farklı C-O titreşiminden kaynaklanan $\sim 1020 \mathrm{~cm}^{-1}$ 
absorbans yoğunluğundaki değişiklikler ile apoptoz, nekrozdan ayırt edilmiştir. Tüm karayosunu ekstreleri uygulanmış hücre gruplarında kontrol grubuyla karşılaştırıldığında $1021 \mathrm{~cm}^{-1}$ ve $1072 \mathrm{~cm}^{-1}$ de nükleik asit bantlarının nispi yoğunluğunda bir azalma olduğu tespit edilmiştir. Yapılan çalışmalar, azalmış DNA absorbansının apoptoz ile ilişkili olduğunu bildirmiştir. $\mathrm{Bu}$, apoptotik DNA'nın daha az IR radyasyonu absorbe etmesiyle açıklanabilir: $\mathrm{Bu}$ tip hücre ölümü sırasında DNA'nın yapısı bozulmasına rağmen "şeffaf" hale gelir. Bunun aksine, nekroz sirasinda DNA bozulur, fakat konsantre edilmez (tam olarak genişler), bu da onun daha fazla k1zılötesi radyasyonu emmesini sağlar. Sadece K3 grubundaki artışa bakıldığında, bu hücrelerde nekrozun olduğu söylenebilir (Abdel-Rauf Ahmed ve ark., 2009; Zelig, 2009).

S. ruraliformis, $H$. andoi ve $P$. riparioides karayosunu türlerinin HCT116 kolorektal kanser hücre hattına karşı yüksek oranda antiproliferatif etki gösterdiği tespit edilmiştir. Deney aşamasında karayosunu türlerinin etkisinin daha iyi belirlenmesi için pozitif kontrol grubu olarak, özellikle kemoterapi tedavisinde etkili bir madde olan sisplatin kullanılmış ve üç karayosunu türünün de $\mathrm{IC}_{50}$ değerlerinin, sisplatinden bile daha düşük olduğu belirlenmiştir. $\mathrm{Bu}$ durum tüm bu türlerin sisplatinden daha düşük dozlarda etkili olduğunu göstermektedir. Ekstreleri hazırlarken kullanılan etil alkol çözücüsünün karayosunu türlerinin bu etkilerini göstermesine katkıda bulunduğu ortaya çıkmıştır. Bunun yanı sıra mezenkimal kök hücrelerine karşı tüm karayosunu türlerinin letal etki göstermemesi ve hücre büyümesini olumsuz etkilememesi bu türlerin sağlıklı hücrelere zarar vermediğinin göstergesidir. Ayrıca, FTIR spektrumu ile elde edilen sonuçların tüm hücre canlılığı verileriyle paralel seyrettiği moleküler düzeyde de belirlenmiştir. Dolayısıyla bu türler, biyoaktif bileşenleri belirlendiği takdirde, potansiyel kanser ilacı olma özelliğine sahiptirler. Tüm yapılan çalışmalar göz önünde bulundurulduğunda $S$. ruraliformis, $H$. andoi ve $P$. riparioides karayosunu türlerinin farmakolojik olarak yapılacak olan araştırmalara yardımcı olabileceği düşünülmektedir. Bununla birlikte çalışmada kullanılan üç farklı karayosunu türünün biyoaktif bileşiklerinin tespit edilmesine yönelik ek çalışmalara ihtiyaç duyulmaktadır.

\section{Teșekkürler}

Nuray Emin'e laboratuvarında yer alan mezenkimal kök hücreleri paylaştığı ve kişisel laboratuvar koşullarını kullanmamızı sağladığı için teşekkür ederiz.

\section{Kaynaklar}

Abdel-Raouf Ahmed G. Khorshid F.A.R. Kumosani T.A. 2009. FT-IR spectroscopy as a tool for identification of apoptosis-induced structural changes in A549 cells treated with PM 701. International Journal of Nano and Biomaterials. 2:1-5, 396-408.

Antonin W. Neumann H. 2016. Chromosome condensation and decondensation during mitosis. Current opinion in cell biology. 40: 15-22.

Asakawa Y. Ludwiczuk A. 2019. Bryophytes as a source of bioactive volatile terpenoids-A review. Food and Chemical Toxicology. 132: 110-649.

Başer F. 2016. Ülkemizde doğal yayılışa sahip karayosunlarından Sphagnum centrale CEO Jensen ve $S$. capillifolium (Ehrh.) Hedw'un (Bryophyta) anti-mikrobiyal aktivitesinin belirlenmesi. Master's thesis, Adnan Menderes Üniversitesi, Fen Bilimleri Enstitüsü.

Barth A. 2007. Infrared spectroscopy of proteins. Biochimica et Biophysica Acta (BBA)Bioenergetics. 1767:9, 1073-1101.

Dey A. Mukherjee A. 2015. Therapeutic potential of bryophytes and derived compounds against cancer. Journal of acute disease. 4:3, 236-248.

Dikmen F. Keçeli T. 2017. Contributions to the Liverwort Flora (Marchantiophyta) of Gürgenli Mountain (Bayramören/Çankırı). Anatolian Bryology. 3:2, 48-57.

Dunkhunthod B. Chitsomboon B. Thummanu K. Sittisart P. 2020. Application of FTIR Microspectroscopy to Monitor Biochemical Changes in Apoptotic Jurkat Cell Death Induced by Extract of Pseuderanthemum palatiferum Leaves. Mt Res Dev 43: 425-40.

Emin N. Mutlu E. Güzel A.E. 2020. Determination the effectiveness of the cytotoxic analysis on the water quality assessments. TURJFAS. 8:2, 478-483.

Erdağ A. Kürschner H. 2017. Türkiye bitkileri listesi: (Karayosunları). ANG Vakfı Yayınevi. İstanbul.

Gasparri F. Muzio M. 2003. Monitoring of apoptosis of HL60 cells by Fouriertransform infrared spectroscopy. Biochemical Journal. 369:2, 239-248.

Gieroba B. Archzewska M. Slawinska-Brych A. Rzeski W. Stepulak A. Gagos M. 2020. Prostate and breast cancer cells death induced by xanthohumol investigated with Fourier transform infrared spectroscopy. Spectrochim. Acta A Mol. Biomol. Spectrosc. 231: 118112. 
Guleken Z. Bulut H. Gültekin G.İ. Arıkan S. Yaylım İ. Hakan M.T. Sönmez D. Tarhan N. Depciuch J. 2021. Assessment of structural protein expression by FTIR and biochemical assays as biomarkers of metabolites response in gastric and colon cancer. Talanta, 231: 122-353.

Hawrył A. Bogucka-Kocka A. Świeboda R. Hawrył M. Stebel A. WaksmundzkaHajnos, M. 2018. Thin-layer chromatography fingerprint and chemometric analysis of selected Bryophyta species with their cytotoxic activity. JPCJournal of Planar Chromatography-Modern TLC. 31:1, 28-35.

Ishida K. P. Griffiths P. R. 1993. Comparison of the amide I/II intensity ratio of solution and solid-state proteins sampled by transmission, attenuated total reflectance, and diffuse reflectance spectrometry. Applied spectroscopy. 47:5, 584-589.

Kırmac1 M. Agcagil E. 2018. The bryophyte flora of Fethiye Babadağ (Muğla/Turkey). Anatolian Bryology. 4:1, 17-30.

McLean M.H. Murray G.I. Stewart K.N. Norrie G. Mayer C. Hold G.L. El-Omar E.M. 2011. The inflammatory microenvironment in colorectal neoplasia. PLoS One. 6:1, e15366.

Mežaka A. Znotiņa V. 2006. Epiphytic bryophytes in old growth forests of slopes, screes and ravines in north-west Latvia. Acta Universitatis Latviensis. 710: 103-116.

Mežaka A. Brūmelis G. Piterāns A. 2008. The distribution of epiphytic bryophyte and lichen species in relation to phorophyte characters in Latvian natural old-growth broad leaved forests. Folia Cryptogamica Estonica. 44: 89-99.

Özerkan D. Erol A. Altuner E.M Canl1 K. Kuruca DS. 2021. Some Bryophytes Trigger Cytotoxicity of Stem Cell-like Population in 5-Fluorouracil Resistant Colon Cancer Cells. Nutrition and Cancer, 1-11.
Parizadeh S.M. Jafarzadeh-Esfehani R. Hassanian SM. Parizadeh S.M.R. Vojdani S. Ghandehari M. Asgharzadeh F. 2019. Targeting cancer stem cells as therapeutic approach in the treatment of colorectal cancer. The international journal of biochemistry \& cell biology. 110: 75-83.

Saxena DK. 2004. Uses of bryophytes, Resonance. 9:6, 56-65.

Sahu R.K. Mordechai S. Manor E. 2008. Nucleic acids absorbance in mid IR and its effect on diagnostic variates during cell division: A case study with lymphoblastic cells. Biopolymers: Original Research on Biomolecules. 89:11, 993-1001.

Serdiuk V. Shogren K. Kovalenko T. Rasulev B. Yaszemski M. Maran A. Voronov A. 2020. Detection of macromolecular inversioninduced structural changes in osteosarcoma cells by FTIR microspectroscopy. Anal. Bioanal. Chem. 412: 7253-62.

Singh S. Srivastava K. 2013. Bryophytes as Green Brain: Unique and Indispensable Small Creature. International Journal of Pharmaceutical Sciences Review and Research. 23:2, 28-35.

Spjut R.W. Suffness M. Cragg G.M. Norris D.H. 1986. Mosses, liverworts, and hornworts screened for antitumor agents. Economic Botany. 40:3, 310.

Yayıntaş O.T. Yılmaz S. Sökmen M. 2019. Determination of antioxidant, antimicrobial and antitumor activity of bryophytes from Mount Ida (Çanakkale, Turkey). Indian Journal of Traditional Knowledge (IJTK). 18:2, 395-401.

Yetgin A. Canlı K. Altuner E.M. 2018. Comparison of antimicrobial activity of Allium sativum cloves from China and Taşköprü, Turkey. Advances in pharmacological sciences. Article ID 9302840.

Zelig U. Kapelushnik J. Moreh R. Mordechai S. Nathan I. 2009. Diagnosis of cell death by means of infrared spectroscopy. Biophysical journal. 97:7, 2107-2114. 